Vox Patrum 6/1986/ 2.10

\title{
$\begin{array}{llllllllllllllllll} & \mathbf{P} & \mathbf{Z} & \mathbf{E} & \mathbf{K} & \mathbf{L} & \mathbf{A} & \mathbf{D} & \mathbf{Y}\end{array}$
}

\section{PISMA ŚW. CYRYLA JEROZOLIMSKIEGO (Epistola ad Constantium imperatorem, Homilia ad paralyticum ad piscinam iacentem)}

Do nieznajych dotad Jezykoni polskienu pism Cyryla Jerozolinsklego /313-386/ nalezaky jeszcze "List do cesarza Konstancjusza - mizj1 krzyza" oraz "Honilia o lezacym przy sadzance paralitykun. rrezentowane przez nas obecnie pierwe $A$ lch tzunaczente kompletuje, razem z przełotonyni praed 15 laty przez ks. Wojclecha Kanie WKate-

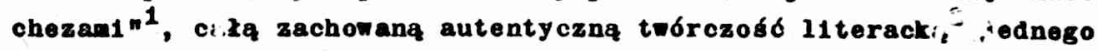
z najwięszych katechetó wczesnochrześcijańskich. Cakości przezozonych pism, czym moze sle poszczycić niewiele tylko krajó, pragniemy-uczcł́ 1600-lecie jego f́mierci, a rómnoczé́nie namiazać do naszych narodowych tradycj1 zwiazanych $z$ tym autoren. $\nabla$ ziazku z powyzsza rocznica warto tu równiez przynajmniej azkicowo przyponuié pierwsze w chrzé́cijarstwie zachodnim polskie zasługi robec tego Ojca Koścloka, zwiazane z restytuowanien 1 opracomanion pierwotnego tekstu krytycznego oraz rozpowszochnieniem go wuropio, tym bardziej, ze sa one często zagranicznych opracowan1ach naukewych przemilozane lub niewystarczajaco ukazywane.

1 Sw. Fyryl Jur xol1msk1, Katechezy, a Jezyki greckiego tivi W.Kania, watgpem opatrzy S.Bojarski, Warszama $1973=$ PSP 9.

2 Por. CPG II, 289-291. 
Vox Patrum 6/1986/z.10

I. Pierwsze - Europie polskie wydanla pism cyryliańskich

o 1le na Zachodzie od czasów wędrówki ludów az po połowę XVI sylwetka, nauka 1 pisma Cyryla Jerozolimskiego pozostawały wupexnym zapomnieniu, spowodowanym nielicznymi 1 ogólnymi tylko przekazami éródłowymi łacińskich autorów wczesnochrześcijańskich ${ }^{3}$, to na Tschodzie pod wpływem licznych informacjl starokościelnych historykó greckich ${ }^{4}$, jego postać była znana, a pisma czytywane 1 cytowane ${ }^{5}$. Co wiecej, pojawiło sie tutaj kilka wschodnich wersji 1 przekładów jego pism ${ }^{6}$, a na przełomie IX $1 X$ w. nawet starosłowianskie tłumaczenie jego Katechez ${ }^{7}$. Przekład ten rozpowszechniony by głómnie na Rusi, wacedonti i Bułgari1, skąd dotarł równiez i do Polski,

3 Z autoró zachodnich mspomina o nim tylko św.Hieronim oraz Rufin. Por. Hieronymus, De viris 111 ustribus 112, PL 23, 705-707, PSP 6, 124: "Cyry 1, blskup Jerozolimy, czesto mypędzany ze swego Kośc1ola znowu do niego powracal. Wreszcie za cesarza Teodozjusza przez osiem lat spokojnie swe biskupstwo posiadar. Sa jego Katecheseis, które "młodośc1 napisał"; tenze, Chronicon ad annum 352, PL 27, 683 /że po śmerci Maksyma zarładnęli Kościołem Jerozolimy arianie, wśród nich Cyry1/; Rueinus, H.E. I 23,37; II 21 /wspomina tylko, ze by następea bpa Jerozolimy Maksyma, oraz o cudownych wydarzeniach $\mathrm{zw}$ iazany ch $\mathrm{z}$ odbudowg swiątyni Jerozolimskiej. Ponadto m swojej "Expositio Symboli" korzystal z 13,14 118 Katechezy Cyryla/.

4 Por. Epistola Concilii Constantinopolitan1/381/ ad Damasum et occidentales, u Teodoreta, H.E. V 9, PG 82,1217/ze cierpial 1 walezyl z artanami/; Epiphanius, Haereses LXVI 20 oraz LXXIII $23,27,37$ /wyinienta tylko jego $1 \mathrm{mię}$ śród innych biskupów/. Zasadniczych informacj 1 dostarczaja: Socrates, H. B. II $38,40,42,45$; III 20 ; IV 4; V 8; Sozomenos, H.E. IV $5,17,20,22,25,30$; VII 7 , 14; Theodoretus, H.E. II $22,26,27$; III $14 ; \mathrm{V} 8,40$; Philostorgius, H.F. IV 12; Joannes Damascenus, Oratio III pro imaginibus; N1cephorus, Chronographia 43; Menaeum Graecorum ad XVIII diem Martil.

5 Por. wymienionych autorów, którzy go cytują w PG 33, 305-320.

6 Np. wersję armeńska Katechez /bez mistagogicznych/ opublikowali w Wiedniu w $1832 \mathrm{r}$. Mechitarzyści, inna por. R.P.Casey, Armenian Inedita, "Museon" 68/1955/55-59; Pragmenty wersji aramaickiej z Palestyny por. H.Duensing, Christlich paldstinisch-aramsische Texte und Fragmente, Gottingen 1906, 41-62; wersje arabskie zob. G.Graf, Geschichte der christlichen arabischen Literatur, I, Città del Vaticano, 1944, 335.

7 Por. A.Valllant, La traduction vieux-slave des Catéchèses de Cyrille de Jérusalem, "Byzantino-slavica" 4/1932/253-302/obok mstepu przytoczony jest przykładowo tekst krytyczny starosłowiańskiego przekładu X katechezy/. 
gdzıe przełozył go znóm na język polski w 1. poł. XVI w. prymas 1 arcybiskup gnieźnieński Jakub Uchańsk1/1502-1581/. Ten przy tłumaczeniu mial prawdopodobnie do dyspozycji starosłowiańska wersje Katechez nie tylko z Macedonil 1 Bułgari1 ${ }^{8}$, ale rómnieź którą́s z rozpowszechnionych na terenach ilusi ${ }^{9}$. On to w oczach późniejszych znawców cyryliańskich Katechez uchodził. takze za lch pierwszego - ogóle wydawcę ${ }^{10}$. Szkoda, ze ten pierwszy polski przekład Katechez gdzlés zaglnął 1 jest dzí́ nieosiagalny, ale mozna przypuszczá, ze - swo1m czasie był on znany 1 wykorzystywany w polemice z reformacja, przynajmniej przez wybitniejszych teologów polskich.

Tak wiec Katechezy Cyryla 1 to $w$ oryginalnym Jezyku greckim, znał, cytował 1 przekładał na łacine $1560 \mathrm{r}$. potrzebne mu eragmenty do walki z reformacja kardynal Stanisław Hozjusz /+ 1579/, legat Stolicy Apostolskiej/1561-1563/ na ostatnie sesje Soboru Trydenckiego, swolm słynnym dziele "Confessio Fidei Catholicae Christiana". Przytaczajac w nim w swej argumentacji, zapewne po raz pierwszy - Buropie, po grecku 1 przekładajac na łacine 221 eragmenty 23 katechezy /IV I fragment V mlstagogicznej/ o Najówiętszym Sakramencie zaznacza, ze podczas swego pobytu w Hzmie konsultował sie z nim

8 Por. Joannes Grodeck, Epistola dedicatoria, in: Catecheses 11luminatorum Hierosolymis XVIII et quinque mystagogicae, Coloniae 1564: "[Catecheses] quas 11le [Uchański] ante compluros annos Sclavorum idiomate conscriptas ex Macedonia et Bulgaria nactus Puerat et in linguam Polonicam transtulerat, suum exemplar Slaronopolonum earundem Catecheseon pro sua benignitate mecum communicavit"; A.Fairre, Cyrille de Jérusalem, Catéchèses, Lyon
1844, t.1, p.3.

9 Por. A.Valllant, La traduction vieux-slave, art.cyt. 281.

10 Tak uwazal np. wybitny wydawca Katechez benedyktyn A.A. Touttée /S. Cyrilil Archiepiscopi Hierosolymitani opera quae exstant omnia, Veneti1s 1763, s.III/, którego tekst niemal dosłownio przedrukowal J.Migne/PG 33/: "Prima Cyrilli editio videtur ea quisse, quam Jacobus Uchański archiepiscopus Gnesnensis regnique Poloniae primas cum Grodecio communicarit. Ille Catecheses Sclaronum idiomate conscriptas ex Macedonia et Bulgaria nactus Puerat ot in Polonicam linguam transtulerat annis pluribus antequam Grodecio, ex quo haec accepimus, suum illud Sclarono-
Polonum exemplar traderet". 
tzumaczaoy oyrylianskie Katechezy z grek1 na lacine protonotariusz apostolski kardynaz wilhelm Sirlet ${ }^{11}$. Jezell teraz uwzglednimy rakt, $\therefore$ dz1ezo Hozjusza /+ 1579/ zyskako sob1e tak wielka poczjtność, 18 jeszcze z: ago zycip rostilo przetzumaczone na pramie wazystkie tjzyki europejskie 1 liczy to at 39 wyde lrukowanych przewaznie za grantea, to mozemy z duma porledziec, te Polacy przyczynill sie pośrednio w zacznya stopniu do zaznajomienia zachodniego chrześc1jaństwa z dwoma przynajmniej katechezami bpa Jerozolimy. z uwagi zá́ Hozjuaza wynika, ze gdy mymle zaczęo mzrastać zainteresnwanie cyrylianskiml Katechezami ze wzgledu na polemike z protestantyzmen, to zarówno on sam, jak 1 Polacy wogólr miell juz opinie znawcón Katechez. Nasuwa sie jednak pytanie, 8k. Hozjusz zdobyl greck 1 ory mał Katechez. Ot6z Jan Grodek InformuJe $1560 \mathrm{r}$., ze greck1 ma. dkrypt Katechez dostarczyl Hozjuszonl podczas jego pobytu (Rzymie stynny patrolog 1 teolog papiesk1 na Soborze Trydenckin Franciszek Torres /1509-1584/, który Juz wczesniej amo1mi laciniskinl przekładami przyblizyl zachodnienu chrzedc1jarstwu wiele patrysty 7 nych p1sm autoró w8chodnich. Kardynaz ucieszyl sie nimi, gdyz zauwazyz, ze moga się one przydá $\mathbf{w}$ walce $z$ reformatorami 12 .

Najwięcej jednak spó́ród Polaków XVI wieku dla upowszechnienia pism Cyryla Jerozolimskiego na Zachodzie uczyniz kanonik wrocławsko-marmínsk1 1 dziekan Głogowa Jan Grodek, kt6ry - po raz plerwszy * Europie - w 1560 r. opublikowal oryginalny grec-

11 Confessio Catholicae Fidel Christiana Petric ensis Synodi nomina a $R$. Stanislao Hosio ep1scopo Varmiensi consoripta, cp. 39, Vioniae in Austria 1560, pp.JXXIb-LXXIe: "Cyr111us quoque Hierosolymitanus Graecus / cuidus Catecheses communicaverat nobiscum Guilhemus Soirletus Proionotarius Apostol1cus, vir pius et dootus, neque mediocri tri:m linguarum peritia praeditus/ in quarta sua Catechesi, quam de hoc sacramento conser1psit, 118 rerbis utitur $/ \ldots \%$ Quas nos ita in latinam linguam convert1mus".

12 Praefat1o, In: S.Cyrill1 mys'sogicae Catecheses quinque ad eos qui sunt recens lluminati. Ioanne Grodec1o interprete, Viennae in Iustria 1560: "Qua /catecheses/ cum Franciscus Torrenais, vir et Graecarum et sacrarum litterarum et insignt quadal letate praeditus, R.D. Varmiensi episcopo, patrono meo colendissimo, cum esset in Urbe legend ledisset, et 1110 rehementer easdem laudaret atque ad BC lae Catholicae dogmata quae nunc a sectarils convelluntur cumprimis utiles esso
diceret". 
k1 tekst wraz z jego lacińskim przekładem 5 katechez mistagogicznych $^{13}$, a nastepnie $\mathbf{1 5 6 4}$ r. zacinski przekład wszystkich katechez wraz z listem do cesarza Konstancjusza o wizj1 krzyza ${ }^{14}$. 0 realizacjl ewego plerwszego przedsiewziecia relacjonuje we wotepic poprzedzajacym raciński przekład 5 katechez mistagogioznych. Opowiada, te gdy byz $/$ Rzymle. spotkaz u kardyna,a Hozje:sza oflarowany mu przez Pranciszka Torresa pochodzacy z Tenecj1 greck1 manuskrypt katechez cyryllarikich, które najpier sam skop1orał, a następie zachecony przez niego 1 przyjacíb postanowiz przełozy 6 na lacinę. Zauwazył jednak, te manuskrypt ten zawiera - sobie wiele lakun 1 błędów, o czym polnfor wał Hozjusza, który znón skierowal go do Torresa. Ten zaś udostępnil Grodkow1 inny waasnorecznie skoplowany 1 przywieziony z Kalabril do faymu manuskrypt, - oparclu o który kanonik warmínski uzupełn1z swój wczé́n1ej przep1sany oryginał grecki 1 przełntyl go na kacinę. Następnie zarónno poprawiony manuskrypt grecki jak 1 sw6j nowy jego przekład racínek1 daz do oceny najpierw Torresowi, a gdy ten go zaaprobowaz, Hozjuszor1, który doradził mu lch rómnoczesne dwujęzyczne opubl1kowante. Grodek zaznacza, ze czyni to nie dla wasnej chwaky/non ea a, causa primum ego transferre/ 1 nie dla szukania elegannjl jezyka, ale pod nac1skien wielu wybitnych q $¥ \delta$, , aby tego rodzaju pisma traktujace o wielkich boskich tajemnscach mogky by 0 w przyszłó́c1 czytane nie przez kilka, lecz przez wiele ośb施.

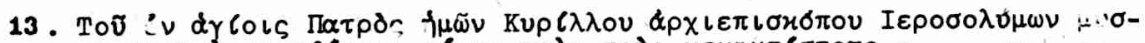

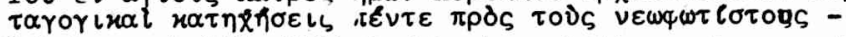
Patrie:atria nostr1 Cyrilli Archiepisoop1 Hierosolymorum cae catecheses quinque, ad oos qui sunt recens 1lluminati. Quae nunc prinue et Graece et Latine simul eduntur, ut qui dubitet de Latinis, ad Graecas possit recurrere, qui Graecas non sau1s Intelligat, Latinas legat. Ioanne Grodecio interprete, Viennae Austriae in aedibus Collegil Caesarii. Societatis Iesu, anno M.D.LX.

14 Catecheses 11 luminatorum IIferosolymis XVIII et quinque mystagogicae. Quae tempore quidem Hi eronym1 et Damascent extabant 11 psi testantur. Nunc primum latinitate donatae in lucem prodeunt Joanne Grodeoio, decano glogoriensi, vratislaviensi varmiexisique canonico interprete, Colonide 1564.

15 Praefatio in: Sancti Cyrilli Mystagogicae Catecheses, dz.cyt.: "eas/catecheses/ego primum mihi ipsi Graece descripsi: leinde rogat's et 1 citatus a familiari quodam amico so, vertere 1 pass in Lc num tentavi. Sed cum mendosum admodum et multis in loos 
Głównym celem opublikowanych katechez miało być, zdaniem Grodka, wykazanie protestantom, ze sakramenty nie są czymś nowym, ale istniały już u początków Kościoła 1 nie moźna ich usuwać lub zmieniać. Żeby jednak publikowany przekład miał większa wiarygodność, wbrew dawnym zwyczajom, dołacza do niego swoje nazwisko ${ }^{16}$. Swiadom jest jednak, ze jest ono zbyt małe 1 nieznane, w zwizzku z czym dla nadania swej publikacji większej powagi 1 znaczenia, decyduje się na dedykorante jej wybitniejszej osobistości. Usiłował ja najplerw, jak sam stwierdza, poświęcić swemu protektorowi Hozjuszowi, a gdy ten jednak zrezygnował, dedykowal ja innemu zde-

mutilum exemplar 1llud, quod erat Venetils scriptum, deprehendissem, et Antistiti meo istud retulissem: ex mandato deinde ilifus cum Francisco Torrensi contuli et ex alio exemplari, quod 1lle manu sua descriptum ex Calabria Homam attulerat, correxi et multa quae defuerant adieci: Postremo et versionem meam subieci lllius ludicio: qui cum ipse diligenter limam adhibuisset et eam approbasset: risum est tandem Praesuli meo, ut utrumque exemplar, et Graecum emendatum et Latinum a me utcunque factum ederetur: ut si quis de Latino exemplari dub1taret, ad Graecum possit facile recurrere. Et quampis non ea de causa primum ego transferre hoc opusculum conatus sum, ut meam translationem istam divulgatam cuperem: sed cum approbatio et voluntas tantorum virorum accessisset, reluctari il11s nolui. Quoniam vero res sacrae divinaque mysteria, in his catechesibus tractantur, nobis quoque a verbis auctoris allquid recedere/nisi cum res aliter intelligi recte non potest/, aut elegantiae magis, quam fide1 studere, religio fuit. Quod si non omnibus tamen, hoc nostro studio satisfacere potuimus: satisfaciat ipse Cyrillus, auctor gravissimus, Graece differens suavissime. Cuius divinas istas catecheses, quae hactenus apud paucos dilitescebant, multis lam passim legere licebit".

16 Tamże, "In quibus edendis hoc unum spectabamus, ut vel ex hox auctore vetustissimo, novatores nostri teuporis intelligant res antiquas et sanctissimas esse et ante tot saecula in Ecclesia Catholica receptas et usitatas fuisse; quae nunc ab illis tantopere convelluntur et profanantur. Id si adsecuti ruerimus, caetera quae nostra privata esse videntur, et nominis et operae nostrae exilis, vulgationem facile negligeremus. Sed quoniam et iampridem recepta fuerat consuetudo et non itapridem a sacris quaesitoribus lex lata est, ut non modo scripta, sed ne versiones pridem ullas suppresso nomine edere liceret: nomen quoque nostrum non prodere non licebat". 
cydowanemu przeciwnikow1 Reformacj1, wielkiemu kanclerzowi koronnemu Janowi 0cieskiemu /1501-1563/, wybitnemu mecenasori, z którego pomocy korzystał podczas swego pobytu w Hzmie ${ }^{17}$.

Wstęp Grodka do wydanych katechez mistagogicznych, będacy źródłem wszystkich powyzszych informacji, zawiera równiez nakreślona w oparciu o relacje Sokratesa /III 20/ 1 Sozomena /IV 29/ charakterystyke działalnośc1 Cyryla, Jego zatargu z metropolita Akacjuszem, oraz krótkie omówienie jego zachowanych pism. Przy tych ostatnich powołując się na przekaz Hieronima stwierdza, ze było $1 \mathrm{ch}$ wiele, ale zachowało sie z nich tylko 18 dotąd nie wydanych Katechez objaśniajacych Symbol Apostolski, oraz 5 katechez mistagogicznych wyjaśniających neofitom sakramenty śfięte ${ }^{18}$. Obok katechez do pism Cyryla zalicza jeszcze tylko List do cesarza Konstancjusza

17 Tamze, "Spectabili et Magnifico Domino Domino Joanni de Ocziessino, Regni Poloniae supremo Cancellario Cracoviensi general1, Ossvienczimen. Zathoriens. Ducatum, ac Sandecensi et olstinensi Capitaneo, Domino et patrono suo colendissimo S.P. addictissimam obsequiorum commendationem. ... Quod cum ipsum/nomen meum/ per se minimum et obscurum sit, clari alicuius riri auctoritate et patrocinio illud subicere atque simul catecheses 1psas dedicare, quo tutius possent in publicum prodire, operae pretium esse putavi. Et quamvis praecipua opera et auctoritate R.D. Varmiensis Episcop1, nunc apud Caesarem Nuntil Apostolic1 domini et Mecenatis mel colendissimi, libellus hic in lucem prodeat, atque 1111 cumprimis et merito insoribi debeat: cum tamen ille, non aliud in hoc quam publicum religionis commodum spectaverit, neque id sibi voluerit adscribl: immo ut cuiusvis potius alterius nomini eundem libellum dicarem, iniunxerit: facere secus mihi non conveniebat, quam ut istas catecheses, tuo magnifice Domine et Patrone colendissime, nomini clarissimo nuncuparem; cuius auspiciis et stypendils ego ab aula in castra humanitatis reversus, annis hisce allquot in Italia bonis litteris operam navavi: In quibus si quid profeci, totum Id amplitudini et beneficentiae tuae acceptum refero at que simul sacras hasce instructiones Cyrilli una cum reliquils studis et obsequils meis 1111 commendo: rogoque maiorem in modum, ut qualecunque hoc studium meum benigne acceptare et favore suo prosequi non graveris. S.M.V. Cliens addictissimus Ioannes Grodecius".

18. Tamze, "Et quamvis permultae illius sacrae institutiones et catecheses litteris mandatae fuerint: quarum etian in Iibro De viris illustribus meminit Hieronymus: quae tamen ad nos pervenerunt, sunt tantum decem et octo catecheses Graece scriptae, et nondum quod sciam typis excusae: quibus primum baptizatos instruit atque totum Symbolum Apostolorum ilis explicat. His additae sunt istae quinque Mystagogicae, quibus divina mysteria de Baptismo, Chrismate, Eucharistia et tremendae Missae sacrificio tradit et explicat". 
- wizji krzyza ${ }^{19}$.

Zarówno w tytule, jak 1 we mstępie, ${ }^{20}$ Grodek podkreśla, ze katechezy mistagogiczne wydawane sa przez niego po grecku 1 po lacinie po raz pierwszy. Zdanie to nie jest pretensjonalną przesadą, bo potwierdzaja ją równiez późniejsze publikacje 1 wydania zagraniczne, z tym, że przeważnie nie zaznaczaja, iż jest to wydanie Grodka Polaka, ale ogólnie - 1ch pierwsze wydanie wiedeńskie z $1560 \mathrm{r}$., tłumacząc sie brakiem dostępu do niego. Tak to czyni zarówno J.Migne 21 , jak 1 ostatni wydawca katechez mistagogicznych w serii "Sources Chrétiennes" A.Piédagnel ${ }^{22}$. U żadnego z nich, jak $i$ u wielu $1 \mathrm{ch}$ poprzedników, nie zrodziło sie nawet przypuszczenie, by autorem tej publikacji mógl być Grodek, że należy Jej rórniez szukać w "dzikiej" Polsce, gdzie egzemplarze tego wy-

19 Tamże, "/.../ ipsius epistola, qua ex Hierosolymis de signo erucis in coelo supra sacrum montem Golgota apparente ad Constantium Agustum scripsit".

20 Iamże, "Cyrillum Hierosolymitanum, cuius istae nunc primum in lucem prodeunt catecheses mystagogicae",

21 Por. PG 33,14: "Editio Viennae a.1560. - i nque mystagogicas Cyrilli catecheses Viennae in Austria Graeve ot Latine editas anno 1560 fuisse, docet catalogus Graecorum codicum Augustanae bibliothecae. Meum de hac editione judicium non interponam, cuius inspiciendae copiam non habui, quamvis diu multumque quaesierim. Idem usu ventt Fabricio, diligentissimo huiusmodi rerum indag tori, qui nullum a se huius editionis exemplar in tota Germania inveniri potuisse testatur".

22 Por. SCh 126, 41-42: "Nous savons que Grodécius, avant de publier en 1564 la première édition latine de l'ensemble des Catéchèses, a connu - c'est lui-même qui nous le dit - un peu avant 1560, une édition slavonne et potonaise. D'autre part, à Vienne, en 1560, Purent éditées en grec, avec une traduction latine, les cinq Catéchéses Mystagogiques. Nous connaissons l'existence de cette édition par le premier catalogue de la Bibliothèque d'Augsbourg, datant de 1575. Mais, ni les grands érudits que furent A.Touttée en France au début du XVIIIe siè-

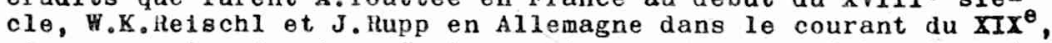
ni aucun autre deputs, n'ont pu retrouver un exemplaire de cette édition". 
dania znajduja sie co najmulej w 6 bibliotekach ${ }^{23}$.

W 4 lata po mydaniu grecko-łacińskiej wersji katechez mistagogicznych, Grodek opublikował, jak już wspominallśmy, w $156 \circ 4$. plerwszy łaciński przekład wszystkich katechez Cyryla, łacznie d mistagoglcznymi 1 Listem do cesarza Konstantyna o wizji krzyza. Ich tekst poprzedzony jest listem dedykacyjnym, w którym znów objaśnia realizację swego pionterskiego przedsięwzięcia, wskazując na jégo cel 1 poświęcając je biskupowi wrocławskiemu Kasprowi z Lagowa/1562$1574 /^{24}$, oraz lkaściwym wstęper zawierającym charakterystykę postaci 1 pism Cyryla.

I tym razem Grodek wiazze geneze swego przekładu z osobą kardynała Hozjusza przypominając, że bęc łc w Hzymie spotkał u niego nigdy jeszcze nie tłumaczony 1 nie wydawany grenki manuskrypt katechez Cyryla z biblioteki protonotariusza apostolskiego kardynała W1lhelma Sirleta, który postanowił przełożyé na łacinę 1 udostępní do czytania innym. Był to zapewne odmienny ma: skrypt niz dostarczony przez Torresa wspominany kodeks z katechezami alstagogicznymi. Gdy - pracy tłumaczeniowej Grodka dowiedział sie w międzyczasie prymas Polski Jakub Uchański, dostarczył mu doknnany przez siebie mspomniany juz polski przekład cyrylianskich katechez z wersji starosłowianskiej. Tłumacz mógł więc teraz zastawíc ze suba oryginalny tekst greck1 z awoma przekładam1, polskim 1 starosłowisńskım, whórych mimo różności języków dostrzegł przedziwną zgodność myśli. Na 1ch podstawie poprawił tłumaczony oryginał grecki, uzupełnił jego braki 1 usunął istniejące w nim błędy ${ }^{25}$. W ten więc sposós Grodek, jak

23 Por. J.Czerniatowicz-Cz.Mazur, Recepcja antyku chrześcijańsílego w Polsce, t.1, cz.1, Lublin 1978, s.45-46, nr 278, gdzie są wyliczone biblioteki i sygnatury egzemplarzy tego wydania.

24 Por. Epistola dedicatoria, in: Catecheses 1llum natorum Hierosolymis XVIII et quinque mystagogicae /../ Nu primum latinitate donatae in lucem prodeunt Ioanne Grodecio interprete, Coloniae 1564: "ileverendissimo in Christo Patri et Domino Domino Caspari Dei gratia Episcopo Vratis aviensi, superioris et inPerioris Silesiae Capitaneo, Domino colendissimo, Ioannes Grodecius Decanus Glogoviensis, Vratislaviensis Varmiensisque Canonicus, florentem relicitatem".

25 Tamze ${ }^{-1}$ tque hoc studio antiquitatis et synacerae veritatis adductus go, cum ante aliquot annes in urbe apud leverendissimum et Ilustrissimum Dominum Stanisiaum Hosium Cardinalem Varmiensem nunc Sanctae Sedis Apostolicae is Concilio Tridentino de latere 
stwierdza T.Sinko, podczas przygotowymania łacínskiego przekładu wszystkich katechez Cyryla Jerozolimskiego, "oprócz kodeksu greckiego otrzymanego za pośrednictwem Hozjusza od Wilhelma Syrleta mial jakís stary przekład starocerkiewno-słowiańsk 1 d dokonany na jego podstawie przez prymasa Jana Uchańskiego przekład polskin'26. Przy dokonywaniu przekładu Grodkowl chodziło nie tyle o elegancje Języka, lle o jak największz wierność, by dla piękna Języka "nie odchodzić od treści Bozych słów 1 świętych tajemnic" ${ }^{27}$. I przy

legatum amplissimum ac Dominum meum clementissimum, nactus essem Graecum exemplar Catecheseon Cyrilli Hierosolymitani Praesulis vetustissiml manu scriptum, neque unquam antea, quod sciam, in sermonem Latinum translatum aut editum. Facturum me nonnulium operae pretium putavi, si 1llud Latinitate donatum aliss quoque syncerae pietatis studiosis passim legendum proponerem. In quo opere perficiundo cum versarem planeque lam illud pereglssem, Reverend1s8imus Dominus Dominus Jacobus Uchanski Archiepiscopus Gnesnensis, Legatus natus Regni Poloniae primas, antiquitatis priscaeque eidel studiosiasimus et in tuenda propagandaque Catholica religione vigilantissimus, posteaquam intellexit me Graecolatinas Cyrilli Hierosolymitani catecheses habere/quas ille ante complures annos Slavonum ldiomate conscriptas ex Macedonia et Bulgaria nactus fuerat et in linguam Polonicam transtulerat/ suum exemplar Slavonopolonum earundem Catecheseon pro sua benignitate mecum communicavit, atque ut translatio utraque una cum origine Graeca conferretur, diligenter curavit. Quo factum est, ut ex mirabili quadam concordia diversae linquae et translationis, constans veritas institutionum commodissime elucesceret. Quamvis enim menda nonnulla et hiatus, qui vitio librariorum committi solent, in utroque exemplari non deessent; et mutua tamen collatione sublatis illis et quae desiderabantur in integrum restitutis: series orationis et doctrinae sic in omnibus concordabat, ut nulla superesse possit suspitio, quin istae catecheses Cyrilii sint verissimae et veteri orthodorae doctrinae coniunctissimae".

26 Lteratura grecka, III, cz.2, Wrockaw 1954, 109, przyp. 108.

27 Bpistola dedicatoria, dz.cyt. "In quibus transferendis veritatis malorem quam elegantiae rationem habendam putavimus, ut quam proxime ad phrasim Cyrilli accederemus. Nam ubi verba divina et sacra traduntur mysteria, periculum est et grande nefas procul ab ipsis rerbis recedere et splendori potius oratiunis quam proprietati simplicis doctrinae studere". 
tej publikacji kanonik wrockawski obszernie uzasadnił jej cel apologetyczny: by dostarczyé argumentów "pochodzących z początków naszej religil 1 z czystych źródez ojców" do walki z reformatorami ${ }^{28}$. We wstępie właśc1mym, napisanym 9 lipca 1563 r. W Trydencie podczas soboru ${ }^{29}$, Grodek scharakteryzował najpierw zycie 1 dzlałalpość Cyryla powołując sie niemal na sposób nowozytny prawle na wszystkie te źródła/Sokrates, Sozomen, Teodoret, Hieronim, Epilaniusz, Nicefor/, którymi 1 dzisiaj posługujemy sie przy odtwarzaniu

Tamże, "Tutius autem et multo consultius fuerit principia nostrae religionis e puris fontibus Patrum haurire, quam turbidos degenerum filiorum rivulos consectari $/ \ldots /$ Quam varietatem et coniunctam 1111 falsitatem qui vitare vult, ad puritatem doctrinae cathoilcae et proxima crescentis Ecclesiae principia recurrat necesse est, atque diligenter consideret, quae tum Puerint sacrae institutiones, quae catecheses, quae mysteriorum explicationes. Quod cum ex alis vetustigsimis sanctorum Patrum scriptis, tum vero ex his Cyrilli Hierosolymitani catechesibus perspicere licet, quibus lile populum Hierosolymitanum ad pietatem instituebat et ea sacrosanctae fidei dogmata tradebat, quae nunc a novarum opinionum cultoribus vehementer convelluntur. Quas quidem catecheses longe commodius esse puto $\theta$ tenebris in lucem proferre et nostrae tempestatis hominibus passim legerdas proponere quam novas aliquas institutiones, utcunque varifs elegentils exornatas, describere. Auctoritas enim et maiestas doctrinae Christianae praeclara est apud antiquos 1110 s et orthodoxos antistites, qui sanam doctrinam et veras traditiones Apostolicas ritusque Ecclesiae a viris Apostolicis instinctu Spiritus sancti institutos in orientali Ecclesia docuerunt, et ad posteros deinceps litteris mandarunt. /... / Opportunum esse putari veteres hasce Cyrilli Catecheses Celsitudini tuae dicare, ut sub tuo amplissimo nomine et auctoritate in lucem prodeant et potius quam pestiferae novatorum catecheses a luventutae priscae fidel studiosa passim lectitentur $/ \ldots /$ mo quoque singularis haec pietas tua et studium religionis catholicae propagandae vehementer commovit, ita ut primo quoque tempore tam pils $1111 \mathrm{~s}$ admonitionibus, cuperem lubens satisfacere; sed cum nondum adsit eius rei praestandae facultas et al1o me nunc trudat legum necessitas, has interim Cyrilli Catecheses, in quibus confirmandae cathoilcae doctrinae causa, pro mea virili elaboravi, tibi pientissime Praesul, qua summa possum animi mel submissione offerro atque dedico $7 . . . / n$.

29 Praefatio, 1n: Catecheses 1lluminatorum Hierosolymis et quinquae mystagogicae /.../ Nunc primum latinitate donatae in lucem prodeunt Ioanne Grodecio interprete, Coloniae 1564: "Soriptum Trident1 durante concilio oecumenico die nona Juli1 Anno Domin1 M.D. LXIII". 
jego biografii. Starał się go ukazać jako zarliwego obrońce bóstwa Chrystusa 1 czystości wiary, za które cierpiał wiele lat wygnania. W podsumowaniu zás jego biografii pisał: "Z tych 1 wielu Innych świadectw pisarzy kościelnych wynika, ze Cyryl by 1 bardzo dzielnym atletą Chrystusa 1 rieustępliwym obrońca ortodoksyjnej wlary, który przez wiele lat o prawdy wiary walczył, róznego rodzaju prześladowania znosiz 1 dobry boj od pierwszych pramie lat cesarza Konstancjusza do wielu lat Teodozjusza roczyzn ${ }^{30}$.

W arugiej zaś części wotępu omóniz pisma Cyryla/Cyrill1a/, stwierdzajac iź moźna przypuszczać, że wiele było zapewne jego kapłańskich $i$ biskupich kazań, komentarzy 1 pouczeń pisanych lub notowanych przez stenografów, ale zachowało si z nich zaledwie 18 katechez o wierze i 5 katechez mistagogicznych, spisanych wprawdie przez innych, ale przez niego zaaprobowanych, Na dowód, ze tych pism było więcej, cytuje po lacinie nieznanq skądinąd grecka "vetustissima annotation, Jaka znalazł przy manuskrypcie Katechez ${ }^{31}$. Nie wymienia tu jednak zadnych innych pism Cyryla: ani nleznanej soble całkowlele homilil a paral tyku, ant listu do Konstancjusza, który wymienił wcześniej przy jego biograpii ${ }^{32}$. Aby zaś udowodnić, że Katechezy były znane, czytywane $i$ wykorzystywane walce z inno-

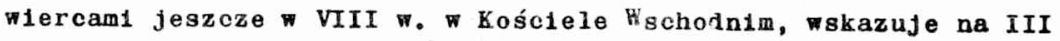
Mowę Jana Damasceńskieg: /+ 749/ przeciw obrazoúbrcom, gdzie *at cytowany fragment XII "ateciezy cvrylicuiskiej, oraz aktua aJe, że 1 dziś po wielu wieks,ch Opatrznośc Boża podaje do rąk Kościo-

30 Praefatio, dz.cyt.

31 Praefatio, dz.cyt.: "Nultae quidem et aliae dictatae sunt institutiones a Cyrillo singulis annis, et ante baptismum et post baptismum, his qui recens fuerant 1 lluminati. Has autem cum dicebantur trecentesimo tricesimo secundo anno adventus Domini nostri Jesu Christi, quidam studiosi excipientes descripserunt, in quibus magna ex parte reperies, secundum Scripturas de omnibus necesarifs fidei dogmatibus, quae expediat venire in cognitionem".

32 Tamże, "Quemadmodum ipse Cyrillus optime id describit in epistola sua, quam de eodem admirando signo ad Constantium impe-
re o $_{3}$ m dederat". 
ła Zachodniego po raz plorwsy wydane po zacinie Katechezy do walki z nowymi heretykami ${ }^{33}$.

Grodek charakteryzuje wreszcie same Katechezy, wskazując na prostote ich jezyka, jasny układ 1 styl, posługlwanle sie nich słowem Bozym, a nie prywatnymi przekonaniami lub filozoficznymi argumentami oraz trzymanie się ducha $i$ przekazywanej przez Kóc16ł Tradycj1 Apostolskiej. Podkré́la równteż zapał 1 zaangazowanie katechety przy podawaniu prawd wiary. Na kontec gtreszcza krótko treść wszystkich katechez, uwypuklając szezególnł a prawdy zwalczane przez reformatorów. Ze względu na to, że takief syntezy Katechez nie powstydziłby się niejeden dzisiejszy patrolog, przytaczamy jej obszerniejszy iragment ${ }^{34}$.

33 Tamże, "Unde etiam liquet easdem catecheses Cyrilli in Orientali Ecclesia olim tempore Damasceni exstitisse, quae nunc post multa saecula in Occidentali et Latina Ecciesia primum eduntur Latine: non sine nutu et providentia quadam divina, ut quo tempore fere in dies exoriuntur novi haeretici veteres haereses renovantes eodem quoque inter allos sanctos Patres prodeat in medium Cyrillus, et in acie $D_{e^{\prime}}$ viventis consistens, suo etiam praeclaro priscae catholicae, e idei testimonio os haereticis obstruat".

34 Tamże, "/.../ et alia Cyrilia dictata seu scripta extit1sse et has quae ad nos perpenere, quaeque nunc in lucem prodeunt catecheses lecem octo et Mystag tae quinque, a studiosis 111 ius inter dicendum litteris ess andatas, ab ipso autem Cyri110 delnceps procul dubio recognitas/quarum etiam Hieronymus facit mentionem et extitisse as Catecheses Cyrilli tempore suo dicit, quas in adolescentia composuerat/. Atque vel hac etiam de causa extemporaneas inscribi: quod non longa meditatione verborumque Puco expolirentur: sed simplici puraque puri verbi Dei interpretatione, prout Spiritus dabat eloqui 111 id captum populi accomodarentur. Id vel e. Ipsa phrasi Cyrilii et orationis compositione moscere licet, quae non persuasibilibus humanae sapientia $3 r b i s$, sed virtute Verbi Dei nititur. Non enim philosophici. ic utitur argumentationibus, non sapientum huius saecul1 grandiloquas propert opiniones, non sui capitis quemadmodum novi catechistae nostri temporis solent, somnia et phantasmata inculcat auditoribus, sed purum Dej Verbum annuntiat meras-. que crepat scripturas, non in privatum aliquem pravumque sensum detortas, sed iuxta sensum et consensum iliius, quae tum plorebat orthodoxae cathollcaeque Ecclesiae. Ut manifeste apparet non privatae opinionis aliquos catechismos lllum instituisse, neque suam allquam novam doctrinam populo tradidisse, sed eam quam a Jacobo Apostolo antecessore suo et ab allis Apostolis per manus traditam acceperat, quam ab Ecclesia catholica didicerat, quam recenti martyrum sanguine confirmatam intellexerat $/ \ldots /$. Cernimus enim in his quam plenus erat divinis eloqui- 
W tak1 oto sposób Polacy, głównie przez Grodka, odkryli 1 ukazali zachodniemu chrześcijaństru katechezy Cyryla Jerozolimskiego; sami najpierw, dzięki bezpośredniemu kontaktowi z Kościołem Wschodnim, poznali je wcześniej z przekładu starosłowiańskiego 1 ruskiego. Swiadectwem tego oddziaływania chrzéscijaństwa Wschodu na kulture polska jest między innymi dokonany $1596 \mathrm{r}$. W Wlnie przez didaskała Stefana zizaniego przekład przypisywanego Cyrylow 1 Jerozolimskiemu apokryeicznego "kazania o Antychryście 1 jego znakach" w rómnoległej wersji polskiej 1 staroruskiej ${ }^{35}$. Zasa-

1s, quam copiosus in proferendis Scripturis, quan animosus in confutandis haereticis, quam fortis rectorum Ecclesiae catholicae dogmatum propugnator. Ac in prioribus quidem octo et decem catechesibus "fotizomenous" eos, qui recenti fide in Christum erant illuuinati instruit de rebus ad baptisnum pertinentibus, et cum primis agit de agnitione peccati quod germen liberif arbitril esse docet, tum de confessione quae baptismum in adultis praecedere solebat, quin et exorcismos commendat plurimum, et quam vim aqua baptismatis habeat ostendit. Deinde dogmata Ecclesiae Catholicae summatim pleraque omnia proponit; quae postremo una cum universo symbolo Apostolico latius explicat et interpretatur.

In posterioribus vero quinque Mystagogicis institutionibus, his qui iam ad solidiorem allquanto doctrinam erant aptiores, solidum cibum tradit divinaque explicat mysteria, de Baptismo, Chrismate, Eucharistia et tremendo Missae sacrificio. Commemorat fere omnes eas ceremonias quae et nunc in Ecclesia Catholica in exhibendis istis sacramentis observari solent ut sunt: Renuntiare sathanae et omnibus operibus eius, symbolum fidei profiteri, Chrismate perungi in Baptismo, manus abluere, osculari invicem, angelorum omnisque caelestis militiae facere commemorationem, sanctos invocare, pro vivis et defunctis orare, et sacrificium Christi corporis et sanguinis offerre in tremendo Missae sacrificio. In omnibus autem his sacris institutionibus non suam aliquam privatam sed publicam puramque Ecclesiae doctrinam sacris oraculis confirmatam ac ab Apostolis traditam defendit".

35 Kazanie S.Cyrylla patriarchy Jerozolimskiego o Antichryście 1 znakach jego, z rozszyrzeniem nauki przeciw herezjam róznym. Kazanie swjatogo Kiryłła patriarchi lerusalimskogo o Antichryste 1 znakoch ego. Wilno 1596. Od stworzenia świata roku $7104,8^{\circ} \mathrm{knlb} .8,214$. Ded. po polsku 1 po słowiańsku do Konstantyna Konstantynowicza Bazylego Ostrogskiego, wojewody kiJowskiego. 
dnicze jednak znaczenie miał tu przekład starosłowiański, bo jak podkreślaja nawet niektórzy autorzy zachodni, on ujawnił dzieło Cyryla Polakom, ci zaś ukazali je całemu katolickiemu światu ${ }^{36}$.

Po pionterskim przedsięwzięclu Grodka zaczęły się pojawiac w Europie Zachodniej nowe wydania Katechez Cyryla. I tak Jeszcze w $r .1564$ mydano łacińsk1 przekład Grodka w izymie, w Antwerpi1 1 dwukrotnie w Paryżu, gdzie również tym czasie pojawia się wydanie WIlhelma Moreli kilkunastu katechez /IV, VI, VIII, IX, X, XV, XVIII-XXIII/ już z tekstem greck1m,z później dołączonym łacińskim tłumaczeniem Grodka. Także Polacy korzystają z odkrycia swego rodaka $^{37}$, a Jakub Wujek umieszeza przełożony na język polski fragment katechezy o Najświ ̨̧tszym Sakramencie, najpierw w 1573 r. w Postyll1 Większej ${ }^{38}$, a następnie w $1596 \mathrm{r}$. w Postyll1 Mniejszej ${ }^{39}$. Trudino odpowiedzieć, czy jest to jego własny przekład z racińskiego tekstu Grodka, czy też może Pragment przekładu Uchańskiego. W 1609 r. pojawia się w Paryzu wznawiane potem dwukrotnie /1631, 1640/ wydanie Jana Prévotiusa zawlerające po raz pierwszy opracowany w oparciu o manuskrypty Biblioteki Watykańskiej tekst grecki wszystkich Katechez obok łacińskiego tłumaczenia Grodka ${ }^{40}$. W XVIII w. na uwage zasługuja dwa duze wydania: angielskie - w Oksfordzie $1703 \mathrm{r} . /$ Tomasza Millesa $z$ tekstem greckim 1 łacińskim przekładem Grodka, które po raz pierwszy umieszcza wśród dzieł Cyryla obok

36 A.Vaillant, La traduction vieux-slave, art.cyt. 281: "A1nsi c'est la traduction vieux-slave qui a révéié loeuvre de Cyrille de Jérusalem aux Polonais, et par leur intermédiaire au monde catholique".

37 Por. J.Czerniatowicz - Cz,Mazur - Recepcja antyku chrześcijańskiego w Polsce, t.1, cz.1, dz. cyt., 45-47.

38 Por. Postilla catholica to jest Kazania na każą niedziele 1 na kaźde święto przez cały rok, Kraków 1573, 298-300: "Cyryla Jerozolimskiego króciuchne kazanie o świętym Sakramencie.

39 Por. Postilla katholicka mniejsza to jest Krótkle kazania abo wykłady świętych Ewangelij/.../ wedle nauki prawdziwej Kościoła Chrześcijańskiego Powszechnego, Kraków 1596, 144-145: S.Cyrilla hróciuchne kazanie o przemienieniu chleba 1 wina w św. Sakramencie"/Hom. IV mistagogiczna/.

40 Catecheses ex varils bibliothecis praecipue Vaticana graece omnes nunc primum in lucem editae cum latina interpretatione Joannis Grodec11, plerisque in locis aucta et emendata, studio et opera Joannie Prevotii Burdegalensis, Parisils 1609. 
Listu do Konstancjusza również "Iomilię o paralityku" w racínskim przełładzie wydawcy ${ }^{41}$ oraz wydanie Prancuskie - w Paryźu/1720 r./ mauryna benedyktyna A.Touttée'a, uwzględniające wszystkie dotychczasore wydania, $z$ nowym tekstem greckim $i$ nowym tłumaczeniem łacińskim ${ }^{42}$; to ostatnie skopiuje niemal dosłownie 1857 r. J.Migne w 33 tomie swej seris Patrologia Graeca. W XIX 1 XX wieku many jeszcze wprawdzie kilka innych wydań Katechez Cyryla, ale ich tu jednak nie wymientany, bo nie maja już one bezpośredniego zwiazku z praca Grodka.

Tak oto wygląda naszk1cowane zaledwie zagadnienie wkładu Polaków XVI T. W odkrycie i popularyzacje Katechez Cyryla Jerozolimskiego $\nabla$ Europie. Celowo przytaczaliśmy w notach duże fragmenty wstępó Grodsa, aby Czytelnik mając kłopoty z dostępem do XVI-wiecznych kodeksów mógł przynajmniej pobieżnie poznać metodę $i$ założenia jego pracy. Problem bowiem nadal pozostaje do rozwizzania: trzeba by koniecznie wyjaśnić tajemnice pierwszego polskiego przekładu Katechez przez Jakuba Uchańskiego - czy faktycznie nie zachował się ani jeden egzenplarz z jego wydania? Należałoby równieź wyjaśnić relacje tłumaczenla Grodka do oryginału greckiego /co to był bliżej za rękopis/ oraz przekładu polskiefo i starosłowiańskiego; warto by wreszcie ukazać wpływ przekładóm starocerkiewnych 1 ruskich na zaznajomienie społeczeństwa polskiego z pismami cyryliańskimi. Odszukanie odpowiedzi na powyższe pytania, do której jesteśmy predysponowani przede wszystkim my, Polacy, stanowiłoby dalszy przyczynek nie tylko is poznania recepcjł myśli patrystycznej waszym kraju, ale równiez uświadomienta sobie naszego wkładu w zapoznanie z nia Kościoła zachodniego.

$$
\text { K 3. Stanisław Longosz - Lublin }
$$

41 S.Patris nostrá Cyrilli Hierosclymorum Archiepiscopi opera quae supersunt omnia, quorim quaedam nunc primum ex codd. mss. contulit plurimis in locis emendavit notisque lllustravit Tho. Milles, uxoniae 1703.

42 S.Cyrilli Archiepiscopi Hierosolymitani opera quae exstant omnia et eius nomine circumferuntir, cur. at studio Antoni Augusti Touttée, Veneti1s 1763 . 
DE ANTIQUISSIMIS I. EUROPA POLONICIS EDITIONIBUS SCRIPTORUM ¿YRIL:.I HI BROSOLYMITANI

/Argumentum/.

Hoc in brevi articulo exponuntur primae in Europa translationes atque editiones scriptorum Cyrilil Hierosolymitani, quae XVI saeculo a Polonis Jacobo Uchański, Stanislao Hosio ac praesertim a Joanne Grodek exaratae sunt. 